\title{
On the History of Ante(s): Exaptation of Adverbial -s?
}

\author{
Dorien Nieuwenhuijsen $\mathbb{D}$ \\ Faculty of Humanities, Department of Languages, Literature and Communication, \\ Utrecht Institute of Linguistics OTS, Utrecht University, 3512 JK Utrecht, The Netherlands; \\ D.Nieuwenhuijsen@uu.nl; Tel.: +31-30-2536363
}

Received: 6 October 2018; Accepted: 19 November 2018; Published: 23 November 2018

check for updates

\begin{abstract}
In this paper we will describe the historical development of the Spanish doublet ante-antes ('before') and explore the question whether a process of exaptation is involved (cf. Lass 1990). We will argue that the final $-s$ of antes, that originally marked the adverbial status of the word, in the course of time had become a kind of morphological 'junk' (cf. Lass 1990) and, subsequently, could be exploited in order to encode the semantic opposition between temporal meaning on the one hand, and adversative meaning on the other hand. However, based on quantitative data we will show that the incipient semantic redistribution over the course of the 16th century rather suddenly collapsed, leading to a differentiation between the prepositional ante and adverbial antes.
\end{abstract}

Keywords: adversativity; ante-antes; exaptation; temporality; preferentiality

\section{Introduction}

Currently, the only productive means to form an adverb in Spanish is by way of the suffix -mente, which is added to the female form of the adjective (lento > lentamente, 'slow' > 'slowly'). This suffix originally was a Latin noun, mens ('mind'), used in the ablative case to indicate the state of mind of someone, and subsequently the way in which an action was performed (Penny 2004, p. 131). However, in Old Spanish the adverbial function could also be explicitly marked by a final $-s$. Since a number of Spanish adverbs of Latin origin already ended in -s (e.g., magis > más, 'more'; laxius > lejos, 'distant'; foras > fueras, 'outside', 'except'), by means of analogy in Old Spanish the $-s$ was added to other adverbs that originally lacked this final consonant (e.g., in tunc > entonces, 'so'; dum interim > domientre > demientre > mientras, 'while'; numquam > nunqua > nunquas, 'never') (Azofra Sierra 2014, p. 377; Corominas and Pascual 1984, p. 277; Menéndez Pidal 1976, p. 296; Penny 2004, p. 131). ${ }^{1}$ Eventually, while some adverbs maintained their analogous -s (e.g., entonces, mientras), other longer forms disappeared, particularly during the Middle Ages (e.g., fueras, nunquas). Still others kept both forms creating doublets, e.g., the adverbs quizá and quizás ('perhaps'), which both express uncertainty or possibility and, according to the Diccionario Panhispánico de Dudas (Real Academia Española 2005, s.v. quizá) are both valid forms.

Another doublet in Modern Spanish is ante-antes ('before') but this pair differs from quizá-quizás, because nowadays the two forms show clear-cut distinctions as far as their functions and meanings are concerned, although in Old Spanish ante y antes had similar functions and meanings.

It is this doublet that we will discuss in detail in the present paper. In Section 2 we will start sketching the historical development of the two adverbs ante and antes. Subsequently, in Sections 3

1 Ortiz Ciscomani (2014) studies adverbial phrases with the preposition $a$ ('to') and a lexical element ending in -as (e.g., $a$ cuestas, 'on one's back'). She states that the -as ending is usually associated with Latin accusative feminine plural, although in many instances of the adverbial phrase scheme there seems to be no logical reason for the use of a feminine plural ending (cf. a ciegas, 'blindly', which is rooted in the adjective ciego, 'blind'). In our view these adverbial phrases differ from simple adverbs like más or lejos, since the final $-s$ in the latter clearly is not a plural marker. 
and 4 we will present quantitative data taken from a corpus especially compiled for the present paper, that will allow us to outline the main distributional similarities and differences between the two forms. Finally, Section 5 summarizes the main findings of our research and discusses their theoretical implications. Particularly, we will focus on the question whether the observed language change can be regarded as a case of exaptation.

\section{The Case of the Spanish Doublet ante-antes}

The Spanish forms ante and antes both derive from Latin ante ('before'), which functioned either as an adverb or preposition. In Old Spanish ante and antes conveyed all the meanings ante already had in Latin, i.e., temporal and spatial meanings, although the longer form antes never appears to have expressed spatial meaning in Spanish (Alvar and Pottier 1993, p. 311; Azofra Sierra 2014, p. 379). ${ }^{2}$ Moreover, derived from the original meaning, ante and antes acquired a more abstract meaning of precedence, to express the idea of preference in comparisons or contrast in adversative relations (cf. Azofra Sierra 2014, pp. 392-96; Cuervo 1886/1994, p. 485; Elvira 2009; Espinosa Elorza 2010, pp. 104-7; Garachana Camarero 1998; Herrero Ruiz de Loizaga 2005, pp. 71-72; Iglesias Recuero 2014, pp. 2560-61 and 2600 ff.; Keniston 1937, p. 630; Menéndez Pidal 1976, p. 393 and 468; Nieuwenhuijsen 2012). These preferential and adversative meanings seem to be a Late Latin or Romance innovation, given that they are not listed in Latin (Azofra Sierra 2014, p. 392; Iglesias Recuero 2014, p. 2560). ${ }^{3}$ In Section 4 we will discuss the different meanings in more detail on the basis of several illustrative examples.

On the other hand, in Modern Spanish ante only functions as a preposition, to locate the position of someone or something in relation to someone or something else (ante el tribunal, 'before the court') i.e., it only retains the spatial meaning that it already had in Latin. ${ }^{4}$ By contrast, antes in Modern Spanish only has an adverbial value, with temporal, preferential or adversative meaning. ${ }^{5}$

Thus, the different functions and meanings of the Latin ante seem to have been redistributed among its two descendent forms ante and antes.

According to Azofra Sierra (2014, pp. 379-80) and Octavio de Toledo y Huerta (Octavio de Toledo y Huerta 2014, p. 1899) the functional differentiation of ante and antes was accomplished in the (mid) 16th century, although Cuervo (Cuervo 1886/1994, p. 480) states that in those days ante sometimes still was used as an adverb, in accordance with the practice of former times.

As far as their meanings are concerned, it appears that in Old Spanish the two adverbs ante and antes were used indifferently to indicate temporal, preferential or adversative meaning. Studies about the evolution of adverbs sometimes treat the two forms as if they were synonymous and stood in free variation to each other, starting with Nebrija (Nebrija 1495/1951) who in his Spanish-Latin vocabulary simply gives "ante o antes adverbio. antea" (cf. also Alvar and Pottier 1993, p. 311; Espinosa Elorza 2010, pp. 104-7; Elvira 2009, p. 105; Iglesias Recuero 2014, pp. 2560 and 2600; Keniston 1937, p. 630; Menéndez Pidal 1982, p. 333).

However, in the case of ante, Octavio de Toledo y Huerta (Octavio de Toledo y Huerta 2014, p. 1899) points at an early tendency of morphosyntactic differentiation of the spatial and temporal meanings, whereby antes came to express temporality, leaving the prepositional ante with the spatial meaning. While, as stated before, this holds true from the mid 16th century onwards, it does not

2 In spite of this, in his dictionary of the Castilian language, originally published in 1886, Cuervo (Cuervo 1886/1994, p. 486) does list the spatial meaning of antes, and although in most of the cited examples antes is combined with de or que, thus becoming a preposition or conjunctive, he also presents some examples of the bare antes, especially used in written texts to refer to something discussed earlier.

3 However, the Oxford Latin Dictionary (Glare 1968-1982, p. 138) includes for the prepositional ante (yet not for the adverbial ante) as its last meaning: "before (in choice, preference, etc.), above, more than".

4 For the development of the preposition ante cf. Octavio de Toledo y Huerta (Octavio de Toledo y Huerta 2014, p. 1897 ff).

5 Antes can behave as a preposition, in Old Spanish as well as Modern Spanish, but only when it is followed by the preposition de (antes del fin de semana, 'before the weekend'). 
explain nor take into account the semantic distribution of ante and antes in their adverbial function in earlier times. Moreover, based on an analysis of a large corpus of examples, Azofra Sierra (2014, pp. 379-80) arrives at some interesting conclusions about the distribution of the two forms and their meanings. She argues that in the 12th and 13th century ante was mainly spatial, whereas antes was temporal. The 14th and 15th century witnessed a predominance of ante with temporal meaning, alongside antes that primarily expressed preferential/adversative meaning. On the other hand, from the 16th century onwards ante was exclusively used for spatial reference, while antes completely seized the temporal meaning, in addition to the preferential/adversative meaning. However, it should be noted that the percentages given by Azofra Sierra (2014, p. 380) reflect the distribution of the three different meanings (locative, temporal and preferential/adversative) within each form separately and, therefore, do not necessarily inform about the preferred form per meaning. For that reason, a closer look at which of the two forms predominated in the 14th and 15th century if preferential/adversative meaning was to be expressed, reveals that in the 15th century it is ante (19 occurrences) which is found more in contexts of preferential/adversative meaning than antes (12 occurrences). The evolution of ante and antes, then, seems to have been less straightforward as Azofra concludes.

In spite of this qualification, the data provided by Azofra seem to suggest that, apart for the functional differentiation between preposition or adverb, an interesting kind of semantic differentiation also took place, in which the adverbial doublet ante-antes was exploited to express different semantic values. At some point in the history of the Spanish language, antes appeared to have been incorporating the preferential and adversative meanings, whereas ante was reserved for temporal meaning. However, this process of redistribution was interrupted quite suddenly in the 16th century, when adverbial ante fell into disuse.

\section{The Data-Distribution of the Forms ante and antes}

In order to check the above summarized claims and study more in detail the functional and semantic development of ante and antes, we collected a corpus of examples taken from the Gradia corpus, which contains 490 documents of different lengths, with different text genres and roughly covers the period from the 12th century to the present. ${ }^{6}$ Since not all genres supply texts for the period in which the development of ante and antes appears to have taken place, we only selected those genres that incorporate texts dating from the 13th century to at least the 16th century. Despite the fact that Azofra Sierra (2014, p. 380) asserts that from the 16th century on ante loses its temporal, preferential, and adversative meanings and only survives with locative meaning as a preposition, for two genres we also included some 17th century texts, in order to assure we would not miss out some of the possibly interesting last cases of adverbial ante. Of every text, we included all cases of adverbial ante (1a and b) and antes ( $2 \mathrm{a}$ and $\mathrm{b}$ ), but eliminated instances of the prepositional ante (3a) and antes de (3b), as well as instances of the conjunctives ante que (4a) and antes que (4b). Thus, our corpus totals 1531 examples, 371 cases of adverbial ante and 1160 of adverbial antes.

(1) a. E despues que el rrey don sancho llego a xerez los dela villa que ante estauan çercados fueron muy conortados conla su venjda. (anonymous, Crónica de Sancho IV, C14) "And after that king don Sancho arrived at Jerez, the people of the city that before were besieged felt very comforted with his arrival".

b. $\quad \mathcal{E}$ no $<n>$ se acuyte de andar ante se tarde por algunos dias fasta $q<u e>$ l rrestauramj $<$ ent $><<0>>$ sea muy bie $<n>$ rreforçado \& co $<n>$ firmado. (Tederico, Cirugía, C16) "and do not hurry to walk rather take some days until the restoration is well reinforced and confirmed".

6 The corpus was originally created by the research group Gradia for their work on verbal periphrases. It covers the following genres: legal, notarial, historiographical, technical, narrative, essayistic, epistolary, philosophical, political, dialogic, journalistic, oral and theatrical texts. The corpus contains over 20 million words. For more details, see http: //gradiadiacronia.wixsite.com/gradia/corpus-gradia. 
(2) a. enlo qual se cumplio lo que Esopo vn poco antes dixera asu amo. (anonymous, Esope historiado, C15) "in which was achieved what Aesop a bit before had said to his master".

b. Mas los xpistianos de tierra de Suria non auien mengua antes auien uiandas assaz. (anonymous, Gran conquista de Ultramar, C13) "But the Christians of the land of Syria did not have lack rather they had a lot of food".

(3) a. $\mathcal{E}$ dixo non fables ante ningun omne fasta que oyas sus palabras. (anonymous, Poridat de poridades, C13) "and he said do not speak before no man until you hear his words".

b. y aunque hacía mal tiempo llegó al puerto Mano á las once horas antes de medio día, (Alonso de Santa Cruz, Crónica del Emperador Carlos V, C16) "and although it was bad weather he arrived at the harbour Mano at eleven o'clock before noon".

(4) a. E ante que muriese mando en su testamento con grand amor que auia a aquella cibdad que ouiera ganado de moros (Diego Rodríguez de Almela, Valerio de las historias eclesiásticas y de España, C15) "And before he died he ordered in his will with great love that he had for that city which he had won from the Moors"

b. y no se han de comer hasta el mes de Agosto, y antes que llueua. (Tomás de Murillo y Velarde, Tratado de raras y peregrinas yervas, que se han hallado en esta Corte, C17) "and they [a certain plant] should not be eaten until the month of August, and before it rains".

In Table 1 we present quantitative data of ante and antes ordered by century.

Table 1. Frequencies of ante and antes per century.

\begin{tabular}{cccc}
\hline Century & ante & antes & Total \\
\hline 13 & $23.1 \%(123)$ & $76.9 \%(409)$ & $100 \%(532)$ \\
14 & $29.9 \%(95)$ & $70.1 \%(223)$ & $100 \%(318)$ \\
15 & $40.6 \%(93)$ & $59.4 \%(136)$ & $100 \%(229)$ \\
16 & $19.5 \%(60)$ & $80.5 \%(248)$ & $100 \%(308)$ \\
17 & $0 \%(0)$ & $100 \%(144)$ & $100 \%(144)$ \\
\hline total & $24.2 \%(371)$ & $75.8 \%(1160)$ & $100 \%(1531)$ \\
\hline \multicolumn{4}{c}{ Chi-square $(4, N=1531)=89.174, p=0.000 * * * 7$}
\end{tabular}

The data of Table 1 show that from the 13th century onwards the corpus contains both adverbs, until the 17th century, when the texts only render cases of adverbial antes, definitely restricting ante to prepositional use, as was already claimed by Azofra Sierra (2014, p. 380). Interestingly, Table 1 also reveals that in the course of time there is fluctuation and co-existence of the two forms (cf. Aitchison 2013, pp. 100-1 and 126), although the non-etymological antes as an adverb has always been more frequent than its counterpart ante.

As mentioned before, in compiling our corpus we selected different text genres, which allows us to check whether the observed evolution is similar for all genres or is more or less prominent according to certain discourse traditions. Table 2 displays the distribution of ante and antes per century in historiographical, philosophical and technical texts. ${ }^{8}$

A closer look at the three different text genres, historiographical texts, philosophical prose and technical texts, puts on display some interesting differences between them. ${ }^{9}$ Whereas in the first genre

7 The result is significant at $p=0.01$. This level of significance is maintained for all chi-square calculations in this chapter.

8 For philosophical and technical texts, we selected all the documents the Gradia corpus contains (717,513 and 833,716 word tokens respectively), for historiographical texts we selected only part of the total amount of texts in this genre. Even so, because we wanted to select several texts per century, the number of word tokens $(2,093,277)$ for this genre is higher than for the other two. It goes without saying that this difference in word tokens does not affect the comparability of the data of Table 2, since the percentages reflect relative frequency.

9 For the present research we selected three historiographical texts from the Gradia corpus. However, as far as the Anales de Aragón by the historian Jerónimo Zurita are concerned, we only took into account a small part of the work (approximately 
adverbial ante, compared to antes, has always been rather rare, in the other two genres the use of ante persists much longer. As Table 2 reveals, the philosophical prose and technical texts pattern together until the 16th century, when use of ante falls to $13 \%$ in philosophical prose, but maintains itself at $59.3 \%$ in technical texts. Interestingly, the decrease of the use of ante (against antes) from the 15th to the 16th century in philosophical prose is statistically significant $\left(p=0.000^{* * *}\right)$, while the apparent retention of ante in technical texts in the 16th century lacks statistical significance. Even so, in the 17th century ante has fallen into disuse in both historiographical and technical texts. Moreover, it merits noting that in philosophical prose the frequency of antes increases steadily over time, while in technical texts the use seems to oscillate and even decrease between the 14th and 16th century.

Table 2. Frequencies of ante and antes per century and per text genre.

\begin{tabular}{ccccccc}
\hline & \multicolumn{2}{c}{ Historiographical } & \multicolumn{2}{c}{ Philosophical } & \multicolumn{2}{c}{ Technical } \\
\hline Century & ante & antes & ante & antes & ante & antes \\
\hline 13 & $4.3 \%(18)$ & $95.7 \%(396)$ & $88 \%(44)$ & $12 \%(6)$ & $89.7 \%(61)$ & $10.3 \%(7)$ \\
14 & $18.1 \%(38)$ & $81.9 \%(172)$ & $53.2 \%(50)$ & $46.8 \%(44)$ & $50 \%(7)$ & $50 \%(7)$ \\
15 & $24.7 \%(20)$ & $75.3 \%(61)$ & $45.9 \%(39)$ & $54.1 \%(46)$ & $54 \%(34)$ & $46 \%(29)$ \\
16 & $0 \%(0)$ & $100 \%(171)$ & $13 \%(6)$ & $87 \%(40)$ & $59.3 \%(54)$ & $40.7 \%(37)$ \\
17 & $0 \%(0)$ & $100 \%(118)$ & -+ & - & $0 \%(0)$ & $100 \%(26)$ \\
\hline total & $7.6 \%(76)$ & $92.4 \%(918)$ & $50.5 \%(139)$ & $49.5 \%(136)$ & $59.5 \%(156)$ & $40.5 \%(106)$ \\
\hline
\end{tabular}

+ For philosophical prose, we do not have data for the 17th century, since the Gradia corpus does not contain texts of this genre for this particular period; historiographical chi-square $(4, N=994)=96.104, p=0.000^{* * *}$; philosophical chi-square $(4, N=275)=54.944, p=0.000^{* * *}$; technical chi-square $(4, N=262)=65.291, p=0.000^{* * *}$.

\section{The Data-Distribution of the Meanings of ante and antes}

As mentioned earlier, in Old Spanish the two adverbs could have temporal, preferential or adversative meanings. The examples grouped under (5) are instances of ante with its different meanings, the examples of (6) correspond to the three meanings of antes.

Whereas the temporal meaning is clearly different from the preferential as well as the adversative meaning, the last two are somehow similar, as they share the idea of precedence. In order to distinguish between preferential and adversative meanings we classified an example as 'preferential' when both the preferred object or action and the second term of the expressed preference were present in the immediate context and the two terms of the comparison referred to the same person or object, as is the case in example (5b) (deuen de morir vs. se dexar venir a seruidumbre, los que son libres) and in (6b) (spirituales vs. corporales, tus mercadurias).

temporal ante

(5) a. de guisa que los faz nacer por fuerça. E a los que son blancos. tinnelos de la color que eran ante. (Alfonso X, Lapidario, C13) "so that it makes them [the hairs] grow forcibly and those that are white it dyes them with the colour they were before".

preferential ante

b. los que son libres ante deuen de morir que se dexar venir a seruidumbre. (Diego Rodríguez de Almela, Valerio de las historias eclesiásticas y de España, C15) "those who are free rather should die than let themselves come to servitude."

adversative ante

215.000 tokens), in order to keep the total number of word tokens for 16th century historiographical prose in relative balance with the total number of word tokens in the 16th century of the other two text genres. It is worth mentioning that in the work of Zurita still five cases of adverbial ante are documented. 
c. E el Respondio le ante te digo que si tu quesieres comer destas verças non seras lisonjero mas diras palabras de verdat (Sancho IV, Castigos y documentos para bien vivir, C14) "And he answered him rather I tell you that if you (would want to) eat from these cabbages, you will not be flattering but will tell the truth"

temporal antes

(6) a. Quiero esso mismo / que sepas que enel tiempo dela peste / aquellos mueren antes / en cuyas casas hay fedores particulares (Taranta, De epidemia et peste. Tratado de la peste, C15) "I also want you to know that in time of the plague those die first in whose houses are particular stenches"

preferential antes

b. E dixo pugna que tus mercadurias sean antes spirituales que corporales (anonymous, Bocados de oro, C13)

"And he said strive that your goods are rather spiritual than corporal"

adversative antes

c. Mas estas cosas no las creyó Alvarado, antes decía que los indios no decían la verdad (Pedro Cieza de León, Las guerras civiles del Perú, C16) "But these things Alvarado did not believe, rather he said that the Indians did not say the truth"

Diachronically, the preferential meaning seems to have been first in developing out of the temporal meaning, followed by the adversative meaning (cf. Azofra Sierra 2014, pp. 379 and 392; Herrero Ruiz de Loizaga 2005, p. 71; Iglesias Recuero 2014, p. 2560; Nieuwenhuijsen 2012), an evolution that is consistent with the idea that priority or preference can lead to adversativity (Garachana Camarero 1998, p. 601). ${ }^{10}$

According to Garachana Camarero (1998, p. 601) adversative connectives like antes signal a notion of priority at the textual level, marking the preference of one argument over another. Elvira (2009, pp. 104-5) characterizes the connective antes as a piece that opposes two elements in a certain part of the discourse and denotes the conceptual or logical preference or priority of one of these elements. Both authors, thus, assume a strong connection between the concepts of priority or preferentiality and adversativity.

In our corpus we find examples that can either have a temporal or a preferential reading. The two meanings share a sense of precedence, which in the case of temporal meaning obviously is related to time, whereas in the case of preferential meaning a more abstract sense of precedence is involved, i.e., the speaker mentally places one event before the other, making an implicit comparison between them. Furthermore, the preferential and the adversative meaning both highlight the notion of precedence, the former making a comparison, the latter stating a contrast. Thus, our corpus also happens to contain examples that allow for either a preferential or an adversative meaning.

First consider (7a), in which, in spite of the fact that the syntactic structure is similar to that of cases with a preferential interpretation, the reading is clearly temporal; the poison does not prefer to do one thing (to kill) to another (the person feeling the poisoning), but, instead, turns out to be mortal before someone becomes aware of its effects. By contrast, in $(7 \mathrm{~b})$ the writer states that the father prefers to die himself instead of witnessing his son's death. However, in this case a temporal relationship between the two events, in principle, is also feasible, because if the father does not wish to see his son dying, inevitably he himself must die first. Examples like $(7 \mathrm{~b})$, therefore, can be considered bridging contexts that give rise to the inference of preferential meaning (cf. Heine 2002). Finally, example (7c) can only have a preferential reading, i.e., the writer asserts that we prefer to help our relative or friend

10 However, Elvira (2009, p. 105) claims the adversative meaning can have arisen as a secondary or inferred reading of examples in which the temporal meaning was also present. He does not seem to assume a preferential meaning in between. 
instead of our neighbour; a temporal relation is very unlikely, if not inconceivable, since it is not the case that we will help our relative or friend before our neighbour.

Subsequently, in (8a) it could be inferred that the birds prefer to hide instead of leaving the caves, but, at the same time, the example can have a contrastive reading, given the marked antithesis between 'leaving the caves' and 'hide themselves', in which case 'rather' could be paraphrased with 'by contrast' or 'on the contrary'. Thus, (8a) and similar examples serve as bridging contexts that induce an inference in favour of the adversative meaning. On the other hand, in (8b) a preferential reading is excluded, since the first statement (es cosa honesta fazer lo que es prouechoso) is made by others ('they say'), whereas the second statement (es honesto non lo fazer) is made by the speaker ('I say'), so there is no comparison of two objects or acts by the same speaker at stake. Therefore, $(8 \mathrm{~b})$ cannot but lead to an adversative interpretation. In fact, in ( $8 \mathrm{~b}$ ) there is a double contrast, i.e., between different speakers ('they' vs. ' $\mathrm{I}$ ') and between different assessments ('it is honest to do something' vs. 'it is honest to refrain from doing that thing').

(7) a. e diz aún que el venino o la poçón d'ellas que ante mata all omne que él sienta el su empoçonamiento, (Alfonso X, General estoria I, C13) "and he even says that the poison or the potion of them [a certain type of snakes] kills the man before he feels its poisoning,"

b. otrosy el padre ante querria ver la su muerte que la de su fijo (Sancho IV, Castigos y documentos para bien vivir, C14) "also the father rather (before) would want to see his death than that of his son"

c. mas sy plejto han en juyz'io. ante ayudaras al pariente $\mathcal{E}$ Al amigo. que al vez'ino. (Alonso de Cartagena, De los oficios, C15) "but when they have a lawsuit in court you will rather help your relative or friend than your neighbour."

(8) a. E las que estan en las arboles $\mathcal{E}$ en las cueuas non osan salir dellas ante punnan de se asconder quanto mas pueden. (Alfonso X, Libro de ajedrez, dados y tablas, C13) "and those [birds] that are in the trees and in the caves do not dare to leave them, rather (on the contrary) they struggle to hide as much as they can."

b. lo que dizen que es cosa honesta. faz'er lo que es prouechoso ante digo yo que es honesto. non lo faz'er (Alonso de Cartagena, De los oficios, C15) "what they say that it is honest to do what is beneficial, rather I say that it is honest not to do it"

In our corpus, the preferential meaning is always less frequent than the temporal and the adversative meanings and, except for the 15th century, the temporal meaning is always more frequent than the adversative one. The relevant data are shown in Table $3 .{ }^{11}$

Taking into account the different genres, it turns out that, although there are some fluctuations per century, overall the percentages per meaning are quite similar; in all three text genres the temporal meaning is most frequent, followed by the adversative and, at a much lower rate, by the preferential meaning (Table 4). Globally, this pattern is maintained for every century, although in historiographical prose in the 14th and 15th century the adversative meaning is slightly more frequent than the temporal one, which is also the case for philosophical texts in the 15th century.

In view of the fact that at least from the 13th century onwards two similar adverbs are available, which apparently seem to be used indiscriminately to express temporal, preferential and adversative meaning, it is conceivable that in the course of time a redistribution of these meanings among the two forms took place. Although, as argued before, there is a semantic continuum between the three meanings, temporality can be placed at one end, whereas adversativity is clearly located at the other end, with preferential meaning bridging the semantic gap between both extremes.

11 In this and the following tables we do not incorporate the data from the 17th century, since they do not show variation between ante and antes. 
Table 3. Frequencies of temporal, preferential and adversative meaning per century.

\begin{tabular}{ccccc}
\hline Century & Temporal & Preferential & Adversative & Total \\
\hline 13 & $77.6 \%(413)$ & $0.9 \%(5)$ & $21.4 \%(114)$ & $100 \%(532)$ \\
14 & $50.3 \%(160)$ & $8.5 \%(27)$ & $41.2 \%(131)$ & $100 \%(318)$ \\
15 & $39.3 \%(90)$ & $10.9 \%(25)$ & $49.8 \%(114)$ & $100 \%(229)$ \\
16 & $53.6 \%(165)$ & $1.6 \%(5)$ & $44.8 \%(138)$ & $100 \%(308)$ \\
\hline total & $59.7 \%(828)$ & $4.5 \%(62)$ & $35.8 \%(497)$ & $100 \%(1387)$ \\
\hline \multicolumn{5}{c}{ chi-square $(6, N=1387)=157.165, p=0.000^{* * *}}$.
\end{tabular}

Table 4. Frequencies of temporal, preferential and adversative meaning per text genre.

\begin{tabular}{ccccc}
\hline Genre & Temporal & Preferential & Adversative & Total \\
\hline Historiographical & $60.6 \%(531)$ & $3.2 \%(28)$ & $36.2 \%(317)$ & $100 \%(876)$ \\
Philosophical & $53.5 \%(147)$ & $10.5 \%(29)$ & $36 \%(99)$ & $100 \%(275)$ \\
Technical & $63.6 \%(150)$ & $2.1 \%(5)$ & $34.3 \%(81)$ & $100 \%(236)$
\end{tabular}

historiographical chi-square $(6, N=876)=133.890, p=0.000^{* * *}$; philosophical chi-square $(6, N=275)=42.334$, $p=0.000^{* * *}$; technical chi-square $(6, N=236)=29.702, p=0.000^{* * *}$.

Therefore, we could hypothesize a dichotomy of form and meaning, in which ante, the etymological Latin form, would stick with the oldest temporal meaning, already present in the Latin ante, whereas antes, the diachronically later form, would seize the Romance novel meaning of adversativity. It should be mentioned that our hypothesis does not make a prediction about the expression of the preferential meaning by one of the two adverbs, since preferential cases on the one hand can be grouped with temporal cases, in which they clearly originate, but on the other hand are also clearly linked to adversative cases, with which they share the meaning of abstract precedence. However, as Table 3 shows, preferential meaning has always been fairly rare in both adverbs.

To test this idea of semantic differentiation, we calculated percentages for ante and antes with the three meanings. Table 5 displays the results.

Table 5. Frequencies of ante and antes per meaning (temporal, preferential, adversative) and per century.

\begin{tabular}{ccccc}
\hline Century & & ante & antes & Total \\
\hline \multirow{4}{*}{13} & Temporal & $23.5 \%(97)$ & $76.5 \%(316)$ & $100 \%(413)$ \\
& Preferential & $40 \%(2)$ & $60 \%(3)$ & $100 \%(5)$ \\
& Adversative & $21.1 \%(24)$ & $78.9 \%(90)$ & $100 \%(114)$ \\
\hline \multirow{3}{*}{14} & Temporal & $37.5 \%(60)$ & $62.5 \%(100)$ & $100 \%(160)$ \\
& Preferential & $40.7 \%(11)$ & $59.3 \%(16)$ & $100 \%(27)$ \\
& Adversative & $18.3 \%(24)$ & $81.7 \%(107)$ & $100 \%(131)$ \\
\hline \multirow{3}{*}{15} & Temporal & $56.7 \%(51)$ & $43.3 \%(39)$ & $100 \%(90)$ \\
\cline { 2 - 5 } & Preferential & $44 \%(11)$ & $56 \%(14)$ & $100 \%(25)$ \\
\cline { 2 - 5 } & Adversative & $27.2 \%(31)$ & $72.8 \%(83)$ & $100 \%(114)$ \\
\hline \multirow{3}{*}{16} & Temporal & $18.8 \%(31)$ & $81.2 \%(134)$ & $100 \%(165)$ \\
\cline { 2 - 5 } & Preferential & $0 \%(0)$ & $100 \%(5)$ & $100 \%(5)$ \\
\cline { 2 - 5 } & Adversative & $21 \%(29)$ & $79 \%(109)$ & $100 \%(138)$ \\
\hline
\end{tabular}

C13 chi-square $(2, N=532)=1.107, p=0.575 ; ;^{12} \mathrm{C} 14$ chi-square $(2, N=318)=14.310, p=0.001$ ***; C15 chi-square $(2$, $N=229)=18.462, p=0.000^{* * *} ;$ C16 chi-square $(2, N=308)=1.467, p=0.480^{12}$.

12 Two cells (33.3\%) have an expected count of less than 5. 
The results of Table 5 do not give evidence of an indisputable gradual spread of antes over the different semantic contexts, i.e., we do not observe a situation whereby antes grasps one meaning at a time (cf. Aitchison 2013, p. 112). Rather, our data point to a state of affairs in which from the 13th to the 16th century the use of adversative antes is always much greater than adversative ante. For example, in the 13th century a figure of $78.9 \%$ is registered for antes with adversative meaning, as opposed to $21.1 \%$ for ante with this same meaning. This pattern is repeated throughout the centuries. Moreover, in every century the percentage of ante's temporal meaning is higher than the percentage of its adversative meaning, except for the 16th century, when ante definitely loses ground as an adverb. Thus, our data reflect a fuzzy situation of co-existence of the two adverbs just before the final blow by antes in the 17th, when ante no longer counted as an adverbial solution (cf. Aitchison 2013, pp. 130-32). ${ }^{13}$

\section{Discussion and Conclusions}

We now turn to the question whether the case of the doublet ante-antes can be conceived as an example of exaptation, a concept which Lass (1990) borrowed from evolutionary biology and applied to language change to describe changes whereby a grammatical distinction coded morphologically is lost without the loss of the corresponding morphological material. This morphology then becomes 'junk', useless material, which subsequently can be exploited for some other function. Lass further states that the domain of exaptation does not have to be morphosyntactic. He considers the semantic splitting of doublets also exaptive, since "if two forms code one meaning, one form is (potential) junk" (1990: 94, note 10).

Over the years, Lass' proposal has been discussed intensively and extensively for different languages. Thus, Vincent (1995) analyses examples from the Romance languages, and Norde (2001) explores the concept of exaptation in the context of Swedish, while Narrog (2007) examines processes of exaptation in Japanese (for a review of some of the early studies on exaptation, see (Traugott 2004)). Particularly, many studies question the notion of 'junk morphology' and, indeed, in later work Lass (1997, pp. 316-24) himself modifies his original idea stating that the availability of junk is not a sine qua non in order for exaptation to take place, and that, on the contrary, functional material can also be exapted. De Cuypere (2005) holds a fairly pessimistic view of the usefulness of the concept of exaptation stating that it "comprises such a broad spectrum of changes that the concept reduces to mere triviality". By contrast, Gardani (2016) argues that exaptation provides valuable insights into the investigation of diachronic change.

Smith (2011, p. 268) calls the kind of language change Lass is referring to 'refunctionalization' or 'adfunctionalization', depending on whether the new function replaces the old one or is simply added to it. Pountain (2000, p. 295) uses the term 'capitalization', in "an attempt to label the historical process by which a linguistic feature which already exists in a language comes to be substantially exploited for wider purposes, sometimes simply making overt distinctions which were previously covert, but sometimes apparently creating new expressive possibilities". Pountain (2000, p. 295)

Finally, in their recent volume on exaptation and language change Norde and Velde (2016, p. 10) adopt a broader, slightly different definition of exaptation, i.e., "the leap-like co-optation of a trait for a new function that is not immediately related to its former function". ${ }^{14}$

Whereas the final $-s$ in Old Spanish could serve to mark adverbs, unarguably in the course of time it lost this function, given that in standard Modern Spanish the only productive adverbial suffix is -mente. ${ }^{15}$ Instead, according to Penny (2004, p. 131) adverbial -s was only an informal means to mark

13 This pattern is repeated in every text genre separately. However, the results are only statistically significant in the case of philosophical prose.

14 See for a thorough state-of-the-art discussion of the notion of exaptation also Norde and Velde (2016, pp. 1-35).

15 Pato and Casanova (2017) report the existence of adverbial cercas alongside cerca in contemporary Mexican Spanish. According to the authors, cercas must be a recent creation, based on analogy with other adverbs that end in -s (such as lejos), since a diachronic review of the form only rendered four occurrences, dating from the 14th to the beginning of the 17th century. Note that currently cercas is a highly stigmatized form in Mexico. Given its recent development and the lack of 
adverbial function, too irregularly applied to count as a genuine suffix. The adverbial morpheme, therefore, at some point in time must have become a sort of junk and must have been no longer recognized as adverbial marker. Now, as Lass (1990, p. 82) states:

here are three things that can in principle be done with it: (i) it can be dumped entirely; (ii) it can be kept as marginal garbage or nonfunctional/nonexpressive residue (suppletion, 'irregularity'); (iii) it can be kept, but instead of being relegated as in (ii), it can be used for something else, perhaps just as systematic. (cf. also Lass 1997, p. 317)

Since ante and antes could both convey different meanings, the felicitous presence of the final $-s$ in antes could be exploited for semantic purpose, i.e., it could be capitalized in order to encode the semantic opposition between the temporal meaning (adverbial ante) and the adversative meaning (adverbial antes). Indeed, our data show a tendency towards Lass' option (iii), as long as both forms are in use as adverbs. ${ }^{16}$ Admittedly, the described tendency does not comply with the definition of exaptation as proposed by Norde and Velde (2016, p. 10), because, as argued before, the different meanings of ante and antes fit in a semantic continuum, being the temporal meaning related to the preferential one, which in turn shares the notion of precedence with the adversative. For that reason, there is no new function involved. Vincent (1995, p. 435, note 4) states:

in the case of exaptation either the meaning was not previously encoded so that only the form pre-exists or else both form and meaning are already present but not combined in the same linguistic sign. (Vincent 1995, p. 435)

The adversative meaning of antes arguably corresponds to the second option of Vincent's definition of exaptation, for in Old Spanish there were other means to convey this meaning, for example, sino ('but') and más bien ('rather'), to mention just two connectives (cf. Elvira 2009; Garachana Camarero 1998; Nieuwenhuijsen 2012).

In the course of the 16th century, ante comes to be exclusively used as a preposition, whereas antes generalizes for adverbial function. Thus, the phonological opposition between ante and antes is exploited to create a clear-cut distinction between word classes. Figure 1 sums up the different functions and meanings of ante and antes and visualizes the changes both forms experienced in the course of time.

The word class distinction inevitably leads to the collapse of the hesitant differentiation between ante expressing temporality and antes expressing adversativity, since, as a consequence, the use of ante as an adverb obviously is ruled out.

Within the scope of the present paper we can only speculate about the cause of this collapse. Certainly, the redistribution of meanings would have led to a transparent distinction between forms and temporal meaning (ante) vs. adversative meaning (antes). However, ante with spatial meaning, inherited from Latin, had always been available in Spanish. Therefore, the semantic differentiation of adverbial ante and antes only sorted out the possible opacity as far as the temporal and adversative meanings were concerned, but it did not take into account the spatial meaning. So, the outcome of this change inevitably would entail a new type of opacity, i.e., the fact that ante designated space as well as time.

Moreover, although in many instances there is a fairly clear semantic difference between the temporal meaning on the one hand and the preferential and adversative meaning on the other hand,

historical evidence, we do not think the existence of contemporary Mexican cercas challenges the claim of unproductiveness of the Old Spanish adverbial suffix $-s$.

16 Interestingly, as mentioned before, other Spanish adverbial doublets chose other options depending on the specific word pair. In the case of fuera-fueras ('outside', 'except'), the second form with final -s has not survived in Modern Spanish (option i); the two members of the doublet quizá-quizás ('perhaps') are both valid forms in Modern Spanish, so the final -s can be considered a non-functional residue of ancient times (option ii). By contrast, in the case of entonces ('so') only the form with final $-s$ has survived. 
these differences perhaps were not salient enough to impose a definitive semantic redistribution of ante and antes, although it does seem to have prompted the distribution as documented in our corpus spanning the period from the 13th to the 16th century.

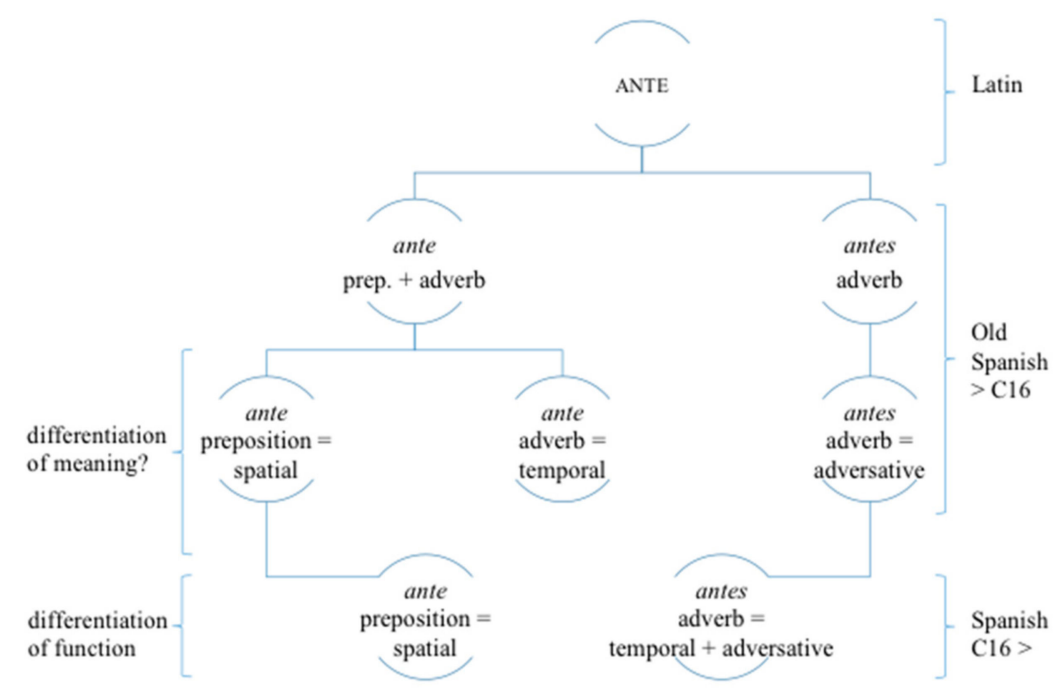

Figure 1. Different functions and meanings of ante and antes in diachronic perspective.

By contrast, the final differentiation created a clear distinction in function between prepositional ante and adverbial antes. At the same time, the change resulted in a distinction between spatial meaning (ante) as opposed to temporal, preferential adversative meaning (antes). It is this distinction that, in retrospect, has prevailed.

Corpus: GRADIA = Corpus compiled by the research group GRADIA. http://gradiadiacronia.wixsite.com/ gradia/corpus-gradia.

Conflicts of Interest: The author declares no conflict of interest.

\section{References}

Alvar, Manuel, and Bernard Pottier. 1993. Morfología Histórica del Español. Madrid: Gredos.

Aitchison, Jean. 2013. Language Change: Progress or Decay? 4th ed. Cambridge: Cambridge University Press.

Azofra Sierra, Elena. 2014. Adverbios de tiempo. Demostrativos comparativos y modo-temporales. In Sintaxis histórica de la lengua española. Tercera parte: Preposiciones, adverbios y conjunciones. Relaciones interoracionales. Edited by Concepción Company Company. Mexico City: Universidad Nacional Autónoma de México \& Fondo de Cultura Económica, vol. 1, pp. 313-410.

Corominas, Joan, and José A. Pascual. 1984. Diccionario Crítico Etimológico Castellano e Hispánico. Madrid: Gredos. Cuervo, Rufino J. 1886/1994. Diccionario de construcción y régimen de la lengua Castellana; Bogotá: Instituto Caro y Cuervo.

De Cuypere, Ludovic. 2005. Exploring exaptation in language change. Folia Linguistica Historica 26: 13-26. [CrossRef]

Elvira, Javier. 2009. Conectores contraargumentativos e castellano medieval. Cahiers d'études hispaniques médiévales 32: 101-15. [CrossRef]

Espinosa Elorza, Rosa M. 2010. Procesos de formación y cambio en las llamadas "palabras gramaticales". San Millán de la Cogolla: Cilengua.

Garachana Camarero, Mar. 1998. La noción de preferencia en la gramaticalización de ahora (que), ahora bien, antes, antes bien y más bien. In Estudios de lingüística cognitiva. Edited by José Luis Cifuentes Honrubia. Alicante: Universidad de Alicante, vol. 2, pp. 593-614.

Gardani, Francesco. 2016. Allogenous exaptation. In Exaptation and Language Change. Edited by Muriel Norde and Freek Van de Velde. Amsterdam and Philadelphia: John Benjamins, pp. 227-60.

Glare, P. G. W. 1968-1982. Oxford Latin Dictionary. Oxford: At het Claredon Press. 
Heine, Bernd. 2002. On the role of context in grammaticalization. In New Reflections on Grammaticalization. Edited by I. Wischer and G. Diewald. Amsterdam and Philadelphia: John Benjamins, pp. 83-102.

Herrero Ruiz de Loizaga, F. Javier. 2005. Sintaxis histórica de la oración compuesta en español. Madrid: Gredos. Iglesias Recuero, Silvia. 2014. Oraciones adversatives. In Sintaxis histórica de la lengua española. Tercera parte: Preposiciones, adverbios y conjunciones. Relaciones interoracionales. Edited by Concepción Company Company. Mexico City: Universidad Nacional Autónoma de México \& Fondo de Cultura Económica, vol. 2, pp. 2519-669.

Keniston, Hayward. 1937. The Syntax of Castilian Prose. The Sixteenth Century. Chicago: The University of Chicago Press.

Lass, Roger. 1990. How to do things with junk: Exaptation in language evolution. Journal of Linguistics 26: 79-102. [CrossRef]

Lass, Roger. 1997. Historical Linguistics and Language Change. Cambridge: Cambridge University Press.

Menéndez Pidal, Ramón. 1976. Cantar de Mio Cid. Texto, Gramática y Vocabulario. Madrid: Espasa Calpe.

Menéndez Pidal, Ramón. 1982. Manual de Gramática Histórica Española. Madrid: Espasa Calpe.

Narrog, Heiko. 2007. Exaptation, Grammaticalization, and Reanalysis. California Linguistics Notes 32: 1-24.

Nebrija, Elio A. de. 1495/1951. Vocabulario español-latino. Madrid: Editorial Castalia.

Nieuwenhuijsen, Dorien. 2012. No es temporal, antes es adversativo: historia del valor adversativo de antes. In Actas del VIII congreso internacional de historia de la lengua Española. Edited by Emilio Montero Cartelle. Santiago de Compostela: Meubook, vol. I, pp. 995-1005.

Norde, Muriel. 2001. Deflexion a a counterdirectional factor in grammatical change. Language Sciences 23: 231-64. [CrossRef]

Norde, Muriel, and Freek Van de Velde. 2016. Exaptation. Taking stock of a controversial notion in linguistics. In Exaptation and Language Change. Edited by Muriel Norde and Freek Van de Velde. Amsterdam and Philadelphia: John Benjamins, pp. 1-35.

Octavio de Toledo y Huerta, Álvaro S. 2014. Otras preposiciones locativas y construcciones afines. In Sintaxis histórica de la lengua española. Tercera parte: Preposiciones, adverbios y conjunciones. Relaciones interoracionales. Edited by Concepción Company Company. Mexico City: Universidad Nacional Autónoma de México \& Fondo de Cultura Económica, vol. 2, pp. 1837-2053.

Ortiz Ciscomani, Rosa M. 2014. Locuciones adverbiales con a y base léxica en -as. In Sintaxis histórica de la lengua española. Tercera parte: Preposiciones, adverbios y conjunciones. Relaciones interoracionales. Edited by Concepción Company Company. Mexico City: Universidad Nacional Autónoma de México \& Fondo de Cultura Económica, vol. 1, pp. 1117-92.

Pato, Enrique, and Vanessa Casanova. 2017. El hotel está muy cercas de la playa, o la falsa pluralización del adverbio cerca en el español de México. Anuario de Letras. Lingüística y Filología 1: 147-67.

Penny, Ralph. 2004. A History of the Spanish Language, 2nd ed. Cambridge: Cambridge University Press.

Pountain, Christopher J. 2000. Capitalización. In Historical Linguistics 1995. Selected papers from the 12th International Conference on Historical Linguistics (= Current Issues in Linguistic Theory, 161). Edited by John Charles Smith and Delia Bentley. General Issues and non-Germanic Languages. Amsterdam and Philadelphia: John Benjamins, vol. 1, pp. 295-309.

Real Academia Española. 2005. Diccionario Panhispánico de Dudas. Available online: http://www.rae.es/ recursos/diccionarios/dpd (accessed on 11 January 2016).

Smith, John C. 2011. Change and Continuity in Form-Function Relationships. In The Cambridge History of the Romance Languages. Edited by Martin Maiden, John Charles Smith and Adam Ledgeway. Cambridge: Cambridge University Press, vol. 1, pp. 268-317.

Traugott, Elizabeth Closs. 2004. Exaptation and Grammaticalization. In Linguistic Studies Based on Corpora. Edited by Minoji Akimoto. Tokyo: Hituzi Syobo Publishing, pp. 133-56.

Vincent, Nigel. 1995. Exaptation and grammaticalization. In Historical Linguistics 1993: Selected papers from the 11th International Conference on Historical Linguistics (= Current Issues in Linguistic Theory, 124). Edited by Henning Andersen. Amsterdam and Philadelphia: John Benjamins, pp. 433-45.

(C) 2018 by the author. Licensee MDPI, Basel, Switzerland. This article is an open access article distributed under the terms and conditions of the Creative Commons Attribution (CC BY) license (http:/ / creativecommons.org/licenses/by/4.0/). 